\title{
Empowerment of Community Business of Scavengers in Landfill of Njawar, Surabaya City
}

\author{
Tri Prasetijowati \\ Faculty of Social and Political Sciences, \\ Bhayangkara University, Surabaya \\ Ratna Setyarahajoe \\ Faculty of Social and Political Sciences, \\ Bhayangkara University, Surabaya \\ Suminah \\ Faculty of Agriculture, \\ Sebelas Maret University, Surakarta \\ Sapja \\ Faculty of Agriculture, \\ Sebelas Maret University, Surakarta
}

\begin{abstract}
Surabaya, the second largest city in Indonesia, has a large scale garbage disposal site or landfill located in Njawar. It is commonly called Njawar Landfill. In this landfill area there are many communities of scavengers living in some villages not far from the landfill site. Although they live in various limitations, still they are able to show their high survival rate due to their assets or potential. During the field identification towards the scavengers, some physical, financial, human resources, and social capital and waste assets have been found. They are still considered in a low condition, except for the waste assets, so that they have less role in finding and developing some activities for the business empowerment of the scavenger community. This research was conducted by combining the quantitative and qualitative methods, and data collection techniques were carried out through questionnaires, observations, interviews and FGDs with the scavenger communities. A simple random technique using confidence intervals was applied for sampling in this study. There were several deep consideration due to the business empowerment for the scavengers of Njawar landfill, and they included the low technology, low income and the exploitation of the collectors on the scavengers. Three dimensions of opportunity, scavenger HR, and accessibility of business sources had been determined for the proposed activities to build the business empowerment of the scavengers.
\end{abstract}

Keywords: business empowerment, scavengers.

\section{INTRODUCTION}

The presence of scavengers is rejected by most of people although they are considered as the spearhead of trash trading. The people still think that the scavengers have the potential to commit theft, they are not trustworthy, and they are also as objects of suspicion. On the other hand, their presence is highly required to minimize the trash or waste, especially inorganic one needed by certain factories, dumped in the landfills or in the Final Disposal Sites. (Kusuma, 2016). In their limited conditions, this community continues to survive and strive for the improvement of their standard of living. It clearly shows that they actually have a potential 
or assets. In the concept of empowerment, according to (Priyono and Pranaka, 2006), a man is the subject of himself which means that there is no human or community that is totally without any assets even though the asset is classified as a low one. The assets owned by the scavengers include physical, human resources, financial and social capital, and waste assets which are considered to be their strengths to build the business empowerment (Sircular,1991) . Based on the description above, the purpose of this research is to find some empowerment activities for the scavenger community in the Njawar landfill to build the business empowerment.

\section{METHODOLOGY}

The location of this study is the City of Surabaya, and the reason to choose it because it is as the second largest city in Indonesia, and become the target of migrants to come in hopes of improving their lives. The subject of this study is the scavengers living in Njawar landfill.

The sampling technique applied in this study is the purposive sampling, and it is used to obtain the valid data. Focus Group Discussion (FGD), independent interviews, and direct observation are also included as the instrument of the study by the author.

The process of data analysis is carried out qualitatively by using the interactive analysis in which there are three main components that must be truly understood by each qualitative researcher. The three main components are (1) data reduction, (2) data presentation, and (3) drawing conclusions and verification (Slamet, Y, 2006).

\section{DISCUSSION}

Identification of existing conditions of scavengers in Njawar landfill, Surabaya

\section{Low level of Technology Owned by Scavengers}

The existing condition of the scavengers is closely related to the level of technology owned by them. It is a very simple, traditional technology, and manually operated. The scavengers only process their products by collecting the piles of garbage, sorting them based on the types, drying them to reduce the water content, then packing them, and finally preparing them to be readily sold to the collectors. Seeing thoroughly the overall conditions experienced by scavengers, some programs to open any business opportunities to empower the scavengers are seriously considered.

\section{Low Revenue of Scavengers}

The income of the scavengers is allocated to both the living necessities and sending some to their families living in the villages. Even though their income is quite low, they are still able to manage their spending and live in such a city like Surabaya. To find out the income of the scavengers, here is the distribution of data presented on a monthly basis.

\begin{tabular}{|c|c|c|c|}
\hline \multicolumn{4}{|c|}{ Distribution of Scavengers Based on Income } \\
\hline No & Income & Number of Persons & $\%$ \\
\hline 1 & $<1.000 .000$ & 12 & 5,8 \\
\hline 2 & $1.000-1.500 .000$ & 209 & 94,2 \\
\hline 4 & $>1.500 .000$ & 0 & 0 \\
\hline & Total & 222 & 100.00 \\
\hline
\end{tabular}

The table above indicates that $94.2 \%$ of the scavengers have their total income ranging from $1,000,000$ to $1,500,000$ Rupiah in one month. It is allocated to support the cost of living, eating, and paying for the boarding homes as well as being sent to the families living in the villages. It can be seen that the income and expenditure of the scavengers are not balance. It can be stated 
that the income is classified as minimal even below the standard of the regional minimum payment. Based on these facts, an opportunity for the scavengers to be empowered is strongly recommended.

\section{Exploitation of Collectors on Scavengers}

The collectors are the business people who have the capital, and utilize the scavengers as their clients who can be controlled to expedite or run their business. The identification of the existing conditions indicated that the collectors in Njawar landfill had little role in processing the waste products. It led to the lower added value of the products which could not increase the income. The role of collectors was more instrumental in which they facilitated the scavengers to sell the products to the product-recycling industry. On the other hand, the scavengers lack the ability or competency in the form of capital and knowledge related to the markets and prices of the products. They did not have any channels to go through a higher level of market. The identification of the existing conditions indicated that the margins of the marketing of recycled products at the landfill level was not high. The small collectors received a margin ranging from $13 \%$ to $49 \%$ while the big ones got around $42 \%$ to $215 \%$ above the price level of the scavenger. If the margin shows that the value of remuneration creates more added value to the product in the marketing chain, the amount of margin received by the collectors is more exploitative and not the added value (quality) for the products.

The potential of the collectors to do any kinds of exploitation on the scavengers can be used as entry points for the empowerment of the scavengers by providing better business opportunities to process the recycled goods so that they have a better selling value to increase the income.

\section{Business empowerment activities for scavengers in Njawar Landfill}

Empowerment is an effort to build the power by encouraging, motivating, and raising awareness of the potential owned and striving to develop it. The aim is to support the scavenger community in Njawar landfill to develop the businesses empowerment to achieve such ideal scavengers with strong characteristics.

a. Receive an income level that can meet the needs of the family to live properly and be able to work independently.

b. Guarantee the rights and obligations, and acknowledge the existence and role in the community in accordance with the state rules and regulations related to the rights and protection.

c. Have the ability to meet the primary needs (clothing, food and shelter) as well as the secondary ones (entertainment, security, affection, and self-esteem).

d. Being widely acknowledged by the people not as a marginal group, but as an institution to strengthen its social roles and functions (Kusuma, 2014)

In an effort to achieve the ideal scavengers with their characteristics mentioned above, the relevant agencies and the Surabaya City Government is necessary to intervene in a pattern of empowerment through the activities below.

The proposed activities to build such business empowerment are as follows: 
A. Dimensions of Business Opportunity

\begin{tabular}{|c|c|c|c|}
\hline Proposed Activities & Aims & Targets & Parties involved \\
\hline 1. Compost Processing & $\begin{array}{l}\text { 1. Increasing the income of } \\
\text { the scavengers } \\
\text { 2. Employment } \\
\text { 3. Increasing the bargaining } \\
\text { position of the scavengers }\end{array}$ & $\begin{array}{l}\text { 1. Scavengers } \\
\text { 2. Collectors } \\
\text { 3. The influential } \\
\text { scavengers }\end{array}$ & $\begin{array}{l}\text { 1. Forestry Service } \\
\text { 2. Cleaning and gardening } \\
\text { services of the city } \\
\text { 3. Provincial Empowerment } \\
\text { Agency }\end{array}$ \\
\hline $\begin{array}{l}\text { 2. Sorting, washing and } \\
\text { milling of scavenging } \\
\text { products }\end{array}$ & $\begin{array}{l}\text { 1. Increasing income } \\
\text { 2. Employment } \\
\text { 3. Increasing the bargaining } \\
\text { position of scavengers }\end{array}$ & $\begin{array}{l}\text { 1. Scavengers } \\
\text { 2. Collectors } \\
\text { 3. The influential } \\
\text { scavengers }\end{array}$ & $\begin{array}{l}\text { 1. Labor offices } \\
\text { 2, Provincial Empowerment } \\
\text { Agency }\end{array}$ \\
\hline 3. Savings and Loan & $\begin{array}{l}\text { 1. Increasing the access of } \\
\text { the scavengers to capital } \\
\text { 2. Being able to escape from } \\
\text { the bonding agent, the } \\
\text { collectors. }\end{array}$ & \begin{tabular}{|l} 
1 Scavengers \\
2. Collectors \\
3. The influential \\
scavengers
\end{tabular} & $\begin{array}{l}\text { 1. Services of Cooperation } \\
\text { and Micro Business of } \\
\text { Surabaya city }\end{array}$ \\
\hline
\end{tabular}

\section{B. HR Dimensions of Scavengers}

\begin{tabular}{|c|c|c|c|}
\hline Proposed Activities & Aims & Targets & Parties involved \\
\hline 1. Social Guidance & $\begin{array}{l}\text { In order to have social } \\
\text { responsibility for the } \\
\text { people or community }\end{array}$ & $\begin{array}{l}\text { Scavengers } \\
\text { and families }\end{array}$ & $\begin{array}{l}\text { 1. Social Services } \\
\text { 2. Education Authorities } \\
\text { 3. Labor Offices } \\
\text { 4. Colleges or Universities } \\
\text { 5. Provincial and City } \\
\quad \text { Empowerment Agencies } \\
\end{array}$ \\
\hline 2.Physical guidance & $\begin{array}{l}\text { kesehatan In order to have } \\
\text { a fit physical condition so } \\
\text { as to maintain health }\end{array}$ & $\begin{array}{l}\text { Scavengers } \\
\text { and families }\end{array}$ & $\begin{array}{l}\text { 1. Social Services } \\
\text { 2. Education Authorities } \\
\text { 3. Labor Offices } \\
\text { 4. Colleges or Universities } \\
\text { 5. Provincial and City } \\
\quad \text { Empowerment Agencies } \\
\end{array}$ \\
\hline $\begin{array}{l}\text { 3. Mental and Religion } \\
\text { Guidance }\end{array}$ & $\begin{array}{l}\text { In order to have religious } \\
\text { awareness so that being } \\
\text { able to hold the religion } \\
\text { well }\end{array}$ & $\begin{array}{l}\text { Scavengers } \\
\text { and families }\end{array}$ & $\begin{array}{l}\text { 1. Social Services } \\
\text { 2. Education Authorities } \\
\text { 3. Labor Offices } \\
\text { 4. Colleges or Universities } \\
\text { 5. Provincial and City } \\
\quad \text { Empowerment Agencies } \\
\end{array}$ \\
\hline 4.Guidance on working skill & $\begin{array}{l}\text { In order to have skills for } \\
\text { self and family interests }\end{array}$ & $\begin{array}{l}\text { Scavengers } \\
\text { and families }\end{array}$ & $\begin{array}{l}\text { 1. Social Services } \\
\text { 2. Education Authorities } \\
\text { 3. Labor Offices } \\
\text { 4. Colleges or Universities } \\
\text { 5. Provincial and City } \\
\text { Empowerment Agencies }\end{array}$ \\
\hline 5. Training on Stuff Sorting & $\begin{array}{l}\text { In order for the } \\
\text { scavengers to know the } \\
\text { types of goods/stuff } \\
\text { collected through sorting } \\
\text { because they will have } \\
\text { lower prices if they are } \\
\text { sold without being sorted } \\
\text { first. }\end{array}$ & $\begin{array}{l}\text { Scavengers } \\
\text { and families }\end{array}$ & $\begin{array}{l}\text { 1. Provincial Empowerment } \\
\text { Agency } \\
\text { 2. Provincial Industry Service }\end{array}$ \\
\hline
\end{tabular}


Prasetijowati, T., Setyarahajoe, R., Suminah., \& Sapja. (2018). Empowerment of Community Business of Scavengers in Landfill of Njawar, Surabaya City. Advances in Social Sciences Research Journal, 5(9) 346-350.

\section{Dimensions of Accessibility to Business Sources}

\begin{tabular}{|c|l|l|l|}
\hline \multicolumn{1}{|c|}{ Proposed Activities } & \multicolumn{1}{|c|}{ Aims } & \multicolumn{1}{c|}{ Targets } & \multicolumn{1}{c|}{ Parties involved } \\
\hline $\begin{array}{l}\text { 1. Partnering with the city } \\
\text { government, and related } \\
\text { offices }\end{array}$ & $\begin{array}{l}\text { 1. Building networks to } \\
\text { facilitate interactions with } \\
\text { related parties }\end{array}$ & $\begin{array}{l}\text { 1. Scavengers } \\
\text { 2. The influential } \\
\text { scavengers }\end{array}$ & $\begin{array}{l}\text { 1. City Government } \\
\text { 2. Services of Cooperation and } \\
\text { Micro Business } \\
\text { 3. Provincial Empowerment } \\
\text { Agency }\end{array}$ \\
\hline $\begin{array}{c}\text { 2. Partnering with non- } \\
\text { government institutions } \\
\text { or private parties, NGOs }\end{array}$ & $\begin{array}{l}\text { 1. To facilitate obtaining } \\
\text { some funds }\end{array}$ & $\begin{array}{l}\text { 1. Scavengers } \\
\text { 2. The influential } \\
\text { scavengers }\end{array}$ & $\begin{array}{l}\text { 1. Private Companies } \\
\text { 2. Government-owned } \\
\text { business entities } \\
\text { 3. NGOs - Non } \\
\text { Government } \\
\text { Organizations }\end{array}$ \\
\hline
\end{tabular}

\section{CONCLUSIONS}

1. Identificaton of the existing conditions of the scavengers in Njawar landfill, and among others are as follows:
a. Lower technology used by scavengers
b. Low income of scavengers
c. Exploitation of collectors on scavengers

2. Businesses Empowerment of scavenger community in Njawar landfill is carried out through 3 dimensions:
a. Dimensions of business opportunities
b. Strengthening human resources
c. Strengthening resource accessibility

\section{BIBLIOGRAPHY}

Kusuma I. 2014. Empowerment model for the garbagepicker base on the asset to improve social living grade at Surabaya. Academic Research International Journal . Vol 4 Maret 2014

Kusuma.2016. The Strategies of Scafenger in Maintaining their viability based on social network in Surabaya City Journal Advances In Social Sciences Research Journal , Vol 3 , Issue 5 May 2016

Priyono, O.S dan Pranaka., 1996, Pemberdayaan Konsep, Kebijakan dan Implementasi, Jakarta: Center For Strategic and International Studies.

Slamet Y, 2006.Metode Penelitian Sosial, Surakarta: Sebelas Maret Univerity Press

Daniel T Sicular,Pockets of Peasant in Indonesia Cities :The Case Of Scavenger,World Development,Vol 9,1991 